\section{[6]Saddlequat: a [6]helquat captured on its racemization pathway $\dagger$}

\author{
Louis Adriaenssens, $\mathfrak{\dagger}^{a}$ Lukáš Severa, $\mathfrak{\dagger}^{a}$ Dušan Koval, ${ }^{a}$ Ivana Císařová, ${ }^{b}$ Marta Martínez Belmonte, ${ }^{c}$ \\ Eduardo C. Escudero-Adán, ${ }^{c}$ Pavlína Novotná, ${ }^{d}$ Petra Sázelová, ${ }^{a}$ Jan Vávra, ${ }^{a}$ Radek Pohl, ${ }^{a}$ David Saman, ${ }^{a}$ \\ Marie Urbanová, ${ }^{e}$ Václav Kašička ${ }^{a}$ and Filip Teplý*a
}

\author{
Received 14th July 2011, Accepted 8th August 2011 \\ DOI: $10.1039 / \mathrm{c} 1 \mathrm{sc00468a}$
}

\begin{abstract}
A dicationic [6] helicene congener captured on the racemization pathway in its saddle-shaped geometry is introduced. Synthesis, structure, resolution, and dynamic properties of this chiral [6]saddlequat in-between and its highly stereocontrolled transformation into enantiopure [6] helquat are discussed and demonstrated. The dynamic aspects established by experiment and supported by detailed DFT-D calculations are presented visually in the form of a movie (electronic table-of-contents and electronic supplementary information). The title [6]saddlequat was found to be an isolable chiral species on the entirely chiral enantiomerization pathway of a [6] helquat that is discussed as an example of Mislow's "rubber glove" molecule.
\end{abstract}

\section{Introduction}

Helicenes and helicene congeners continue to attract attention due to their fascinating helical shape, inherent chirality, and electronics. ${ }^{1-4}$ Because of their unique structure, their selfassembly, ${ }^{5,6}$ catalytic, $^{7}$ chiroptical, ${ }^{8}$ and acid-base ${ }^{9}$ properties have been intensively studied. Furthermore, the recently reported ability of helicene congeners to inhibit the activity of telomerase ${ }^{10}$ topoisomerase $\mathrm{I},{ }^{11}$ and interact with DNA duplexes ${ }^{12}$ and $\mathrm{G}$ quadruplexes ${ }^{13}$ promises interesting future applications.

A distinctive feature of helicenes is the existence of a thermal racemization pathway equilibrating the right-handed helix with the left-handed one $(P \rightleftharpoons M$, Scheme 1 and Scheme 2). This unique phenomenon of thermally triggered racemization via helix inversion has been extensively investigated. ${ }^{14-17}$ In a typical helicene, e.g. [6] helicene, helix inversion proceeds via a $C_{\mathrm{s}^{-}}$ symmetric saddle-shaped transition state that is achiral

${ }^{a}$ Institute of Organic Chemistry and Biochemistry, Academy of Sciences of the Czech Republic, v. v. i., Flemingovo nám. 2, Prague, 166 10, Czech Republic. E-mail: teply@uochb.cas.cz; Fax: +420-220 183 578; Tel: +420-220183412

${ }^{b}$ Department of Inorganic Chemistry, Charles University, Hlavova 2030, 12840 Prague 2, Czech Republic

'Institute of Chemical Research of Catalonia (ICIQ), Av. Països Catalans 16, 43007 Tarragona, Spain

${ }^{d}$ Department of Analytical Chemistry, Institute of Chemical Technology, Technická 5, Prague, 166 28, Czech Republic

${ }^{e}$ Department of Physics and Measurements, Institute of Chemical Technology, Prague, Technická 5, Prague, 166 28, Czech Republic

$\dagger$ Electronic supplementary information (ESI) available: Experimental and theoretical procedures, synthesis, spectroscopic, and crystallographic data. CCDC reference numbers 828959, 829265-829267. For ESI and crystallographic data in CIF or other electronic format see DOI: $10.1039 / \mathrm{c} 1 \mathrm{sc} 00468 \mathrm{a}$

\$ These authors contributed equally to this work.
(Scheme 1a). ${ }^{16}$ In some rare cases, helicene congeners having saddle-shaped energy minima on their racemization pathways have been reported. Two examples, where the presence of such
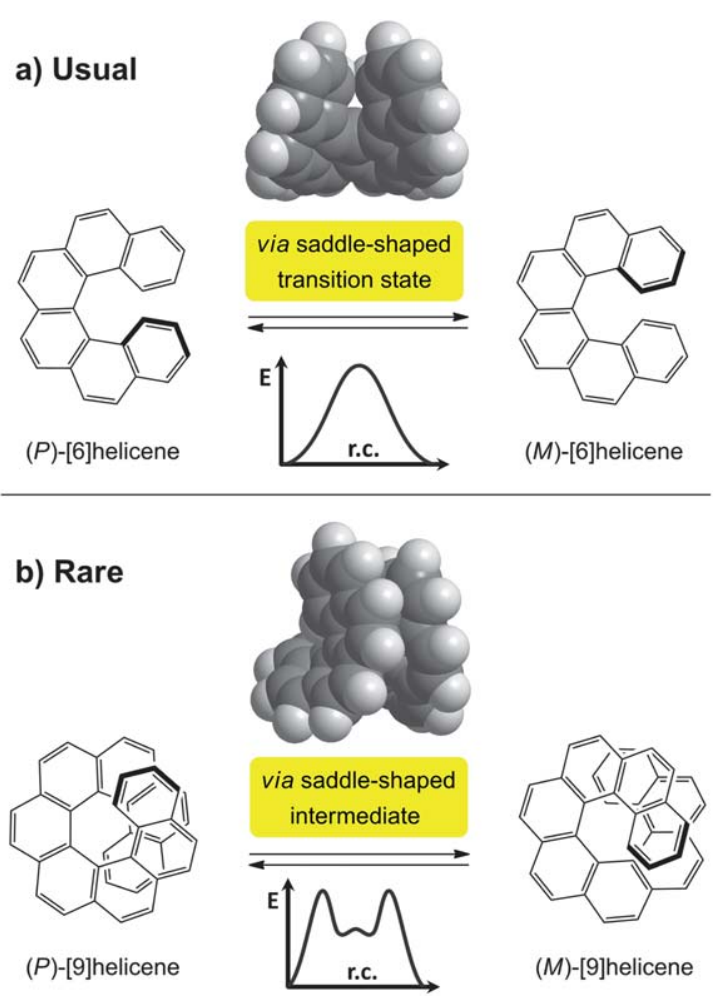

(M)-[9]helicene

Scheme 1 (a) Racemization of [6]helicene via achiral saddle-shaped transition state, (b) racemization of [9]helicene via saddle-shaped intermediate, and the corresponding energy profiles. r.c. $=$ reaction coordinate. 


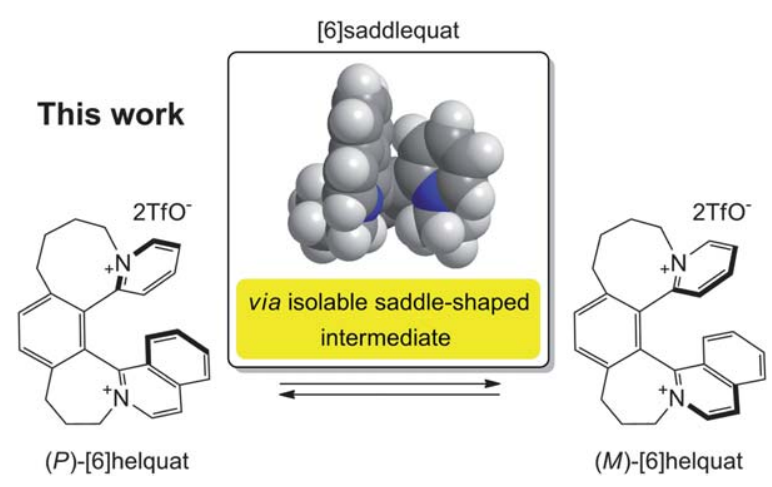

Scheme 2 Racemization of [6] helicene congener via isolable saddleshaped intermediate studied in this work.

saddle-shaped energy minima is predicted, are [9] helicene (Scheme $1 b)^{16 b}$ and a recently disclosed [11]helicene derivative. ${ }^{17,18} \mathrm{We}$ supposed, if the saddle-shaped energy minima existed in a sufficiently deep energy valley, then, the species corresponding to these minima could, in principle, be isolated and characterized as stable intermediates. They would represent a helical system captured during its racemization pathway.

Here we describe the synthesis, structure, and dynamic properties of a [6]helquat, a dicationic [6]helicene congener captured on the racemization pathway in its saddle-shaped geometry (Scheme 2). Resolution of this chiral saddle-shaped species and its highly stereocontrolled transformation into enantiopure [6]helquat is demonstrated.

\section{Results and discussion}

In our recent studies, we introduced helquats, ${ }^{19-22}$ helical dications that represent a missing structural link between helicenes and viologens. By taking advantage of a highly flexible three-step synthetic route, ${ }^{21}$ we accessed isomeric triynes $\mathbf{1}$ and $\mathbf{3}$ (Scheme 3 and $\mathrm{ESI} \dagger)$. We found that, as usual, triyne $\mathbf{1}$ is transformed solely to the corresponding [6] helquat 2 via rhodium-catalyzed [ $2+2+$ 2] cycloaddition. ${ }^{23,24}$ However, the isomeric triyne $\mathbf{3}$ leads under the same reaction conditions to formation of an isolable saddle-
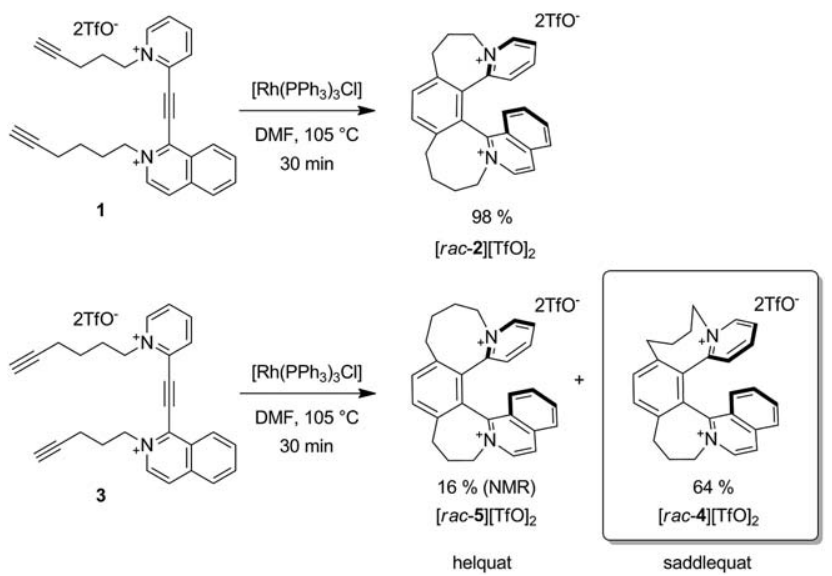

Scheme 3 Triyne 1 leads solely to helical product $\mathbf{2}$ while isomeric triyne $\mathbf{3}$ gives the saddle-shaped species $\mathbf{4}$ as the major product. shaped species $\mathbf{4}$ along with the formation of [6]helquat $\mathbf{5}$, featuring the typical helical shape. Both structures $\mathbf{4}$ and $\mathbf{5}$ were confirmed by a variety of spectroscopic methods. ${ }^{13} \mathrm{C},{ }^{1} \mathrm{H}, \mathrm{HSQC}$, HMBC, COSY and ROESY NMR spectra permitted full assignment of all ${ }^{1} \mathrm{H}$ and ${ }^{13} \mathrm{C}$ resonances and established connectivity and spatial arrangement. Importantly, the threedimensional identity of the individual dicationic frameworks has been unambiguously proved by single-crystal X-ray diffraction analyses (vide infra). ${ }^{23}$

The saddle-shaped product $\mathbf{4}$, which we suggest to denote as [6]saddlequat 4, arises from a kinetically controlled $[\mathrm{Rh}$ $\left.\left(\mathrm{PPh}_{3}\right)_{3} \mathrm{Cl}\right]$-catalyzed [2+2+2] cycloisomerization that furnishes a mixture of [6]saddlequat 4 and the corresponding [6]helquat 5 in a $4: 1$ ratio. ${ }^{25}$ The solubilities of the diastereoisomeric salts [4] $[\mathrm{TfO}]_{2}$ and $[\mathbf{5}][\mathrm{TfO}]_{2}$ in tetrahydrofuran are considerably different and allow for the straightforward non-chromatographic separation of the two stereoisomers. Notably, and of particular importance for this study is that the saddle-shaped species [4] is sufficiently long-lived to be comfortably studied experimentally.

Moreover, both [5] and [4] are chiral entities formed as racemates during the $[2+2+2]$ cycloaddition depicted in Scheme 3 . This is evidenced by capillary electrophoresis (CE) with sulfated $\gamma$-cyclodextrin chiral selector, which shows two peaks of equal intensity corresponding to the two enantiomers of compound 4 (Scheme 4). A similar situation is observed in the case of compound $\mathbf{5 .}{ }^{26,27}$

The calculated Gibbs free energy of the saddlequat [4] is $18 \mathrm{~kJ}$ $\mathrm{mol}^{-1}$ higher relative to helquat [5] in DMSO as determined by DFT-D calculations ${ }^{28}$ (TURBOMOLE: ${ }^{29}$ B3LYP/def2-TZVP// ri-PBE/def2-SV(P) + disp ${ }^{30}+\mathrm{DMSO}^{31}$ see ESI for details $\left.\dagger^{32}\right)$. In line with this predicted energy difference, upon heating in DMSO- $d_{6}$ at $100{ }^{\circ} \mathrm{C}$ saddlequat $[4][\mathrm{TfO}]_{2}$ gradually and completely converted to helquat $[5]\left[\mathrm{TfO}_{2}\right.$ (Scheme 5). This process can be followed by NMR via disappearance of peaks corresponding to [4] and appearance of peaks corresponding to [5] (Scheme 5). Data analysis from this experiment led to the activation free energy value $\Delta G^{\neq}$of $120 \mathrm{~kJ} \mathrm{~mol}^{-1}$ for the transformation [4] $\rightarrow$ [5].

In order to gain a thorough understanding of the conversion of [4] to [5] we turned to detailed DFT calculations. To this end,

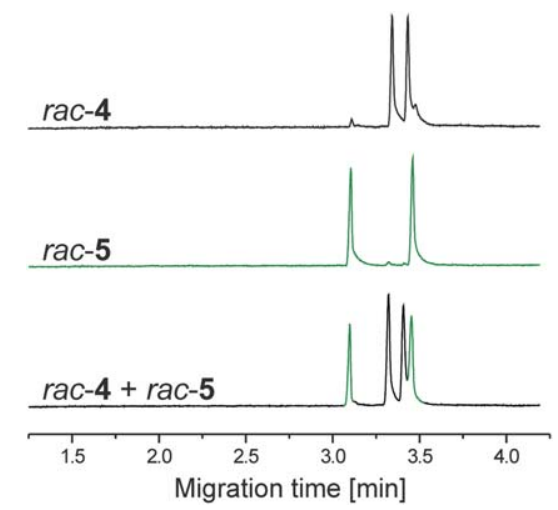

Scheme 4 Saddlequat [4] and helquat [5] are both chiral entities. Both, [4] and [5], are produced from the triyne 3 in racemic form as evidenced by capillary electrophoresis with sulfated $\gamma$-cyclodextrin chiral selector. ${ }^{27}$ See ESI for details. $\uparrow$ 


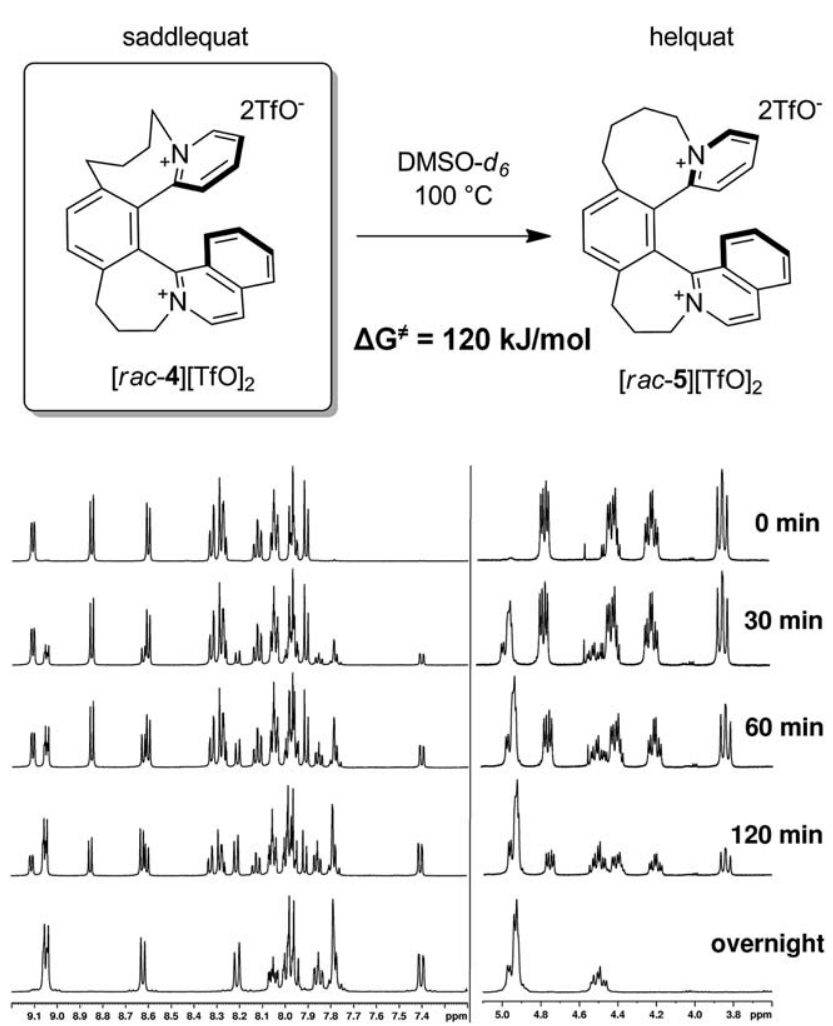

Scheme 5 Transformation $[\mathrm{rac}-4] \rightarrow[\mathrm{rac}-5]$ at $100{ }^{\circ} \mathrm{C}$ in DMSO- $d_{6}$ followed by ${ }^{1} \mathrm{H}$ NMR.

TURBOMOLE calculations at the DFT-D level ${ }^{28-31}$ shed light on the energy profile of and structures involved in the entire racemization pathway of helquat [5] (Scheme 6). In line with our experimental results, calculation predicts that the saddlequat [4] exists in this calculated energy profile as a local energy minimum that is in a sufficiently deep energy valley that it can be isolated and studied.

Inspection of the calculated energy profile around saddlequat [4] indicates that there are two possible, energetically distinct, pathways leading to two helquat [5] structures of opposite helicity (pathways a and b in Scheme 6). The lower, pathway a, corresponds to a $\Delta G^{\neq}$value of $119 \mathrm{~kJ} \mathrm{~mol}^{-1}$, which fits very well with the experimentally determined value of $120 \mathrm{~kJ} \mathrm{~mol}^{-1}$ for transformation [4] $\rightarrow$ [5] (see NMR study, Scheme 5). Following the energetically less favorable pathway $b$ would also transform the same saddlequat to helquat, but now to the helquat of the opposite helicity.

We thus speculated that the existence of these two energetically distinct pathways would allow for the stereocontrolled transformation of enantiopure saddlequat [4] into enantiopure helquat [5] (via pathway a in Scheme 6). To test this hypothesis, access to non-racemic [4] was crucial. Therefore, we turned to resolution of racemic [4]. By employing the same resolution protocol recently reported for a [5] helquat derivative, ${ }^{20,33}$ we were able to achieve straightforward resolution of $[\mathrm{rac}-4][\mathrm{TfO}]_{2}$ (Scheme 7). Specifically, the exchange of triflate anions in [ $\mathrm{rac}-4]$ $[\mathrm{TfO}]_{2}$ for enantiopure $(R, R)$-dibenzoyltartrate anions led to the formation of two diastereomeric salts, one of which crystallized from methanol in diastereomerically pure form, as evidenced by a single peak in the chiral CE trace. ${ }^{26,27}$ Single crystals suitable for X-ray diffraction analysis were obtained and enabled absolute configuration assignment of the dicationic scaffold of $\left[S_{a}, R_{a}-4\right]$ (Fig. 1). ${ }^{23}$ Subsequent exchange of the $(R, R)$-dibenzoyltartrate anions in this diastereomerically pure salt for triflate anions via ion exchange resin completed the resolution giving (+)-[ $\left[S_{a}, R_{a}-4\right]$ ditriflate in its enantiomerically pure form (CE in Scheme 7).

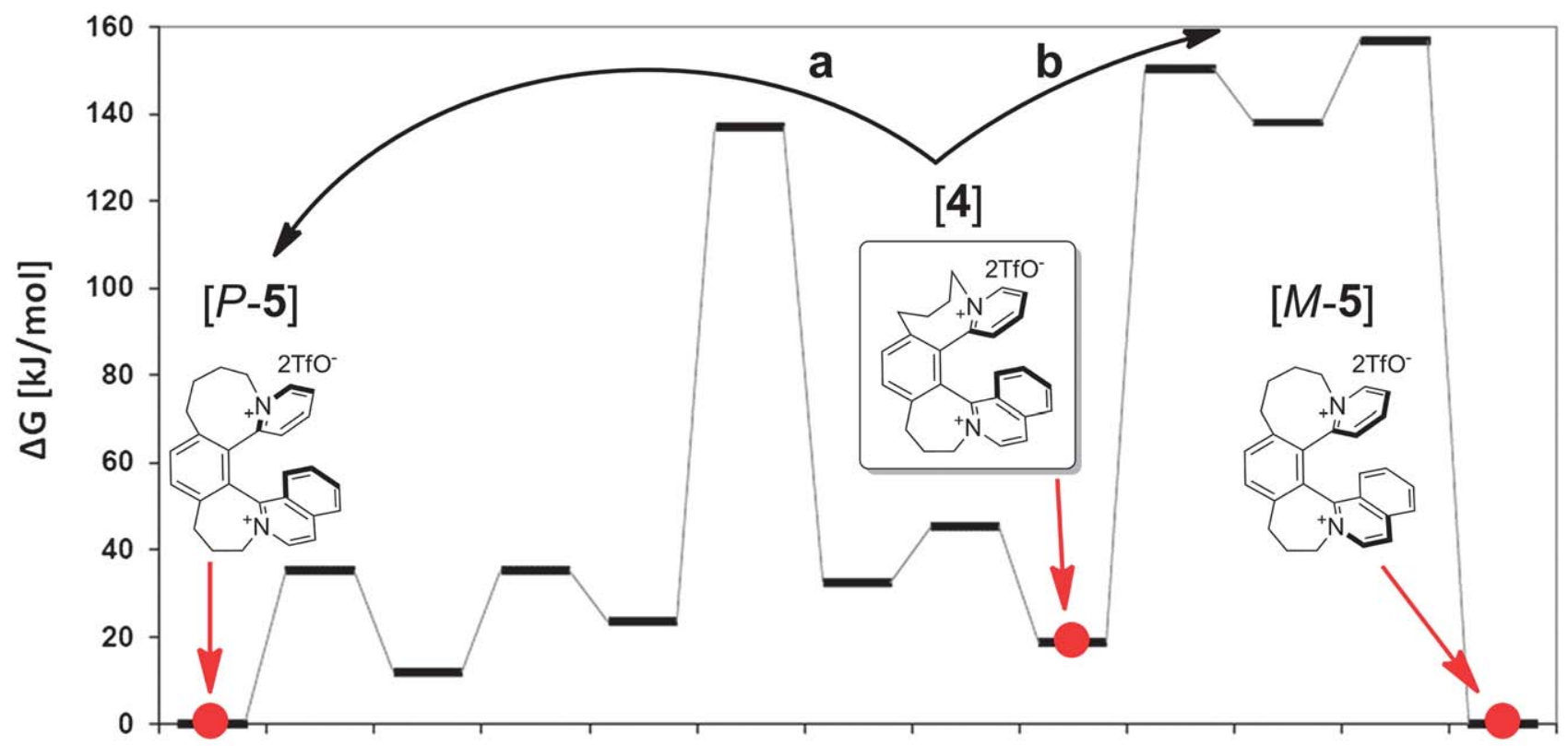

r.C.

Scheme 6 Calculated racemization pathway of helquat [5] passing through saddlequat [4]. Pathways a and b denote the two distinct routes from saddlequat [4] to the two enantiomeric helquats $[P-5]$ and $[M-5]$, respectively. See also the movie in the electronic table-of-contents and ESI for details. $\dagger$ 

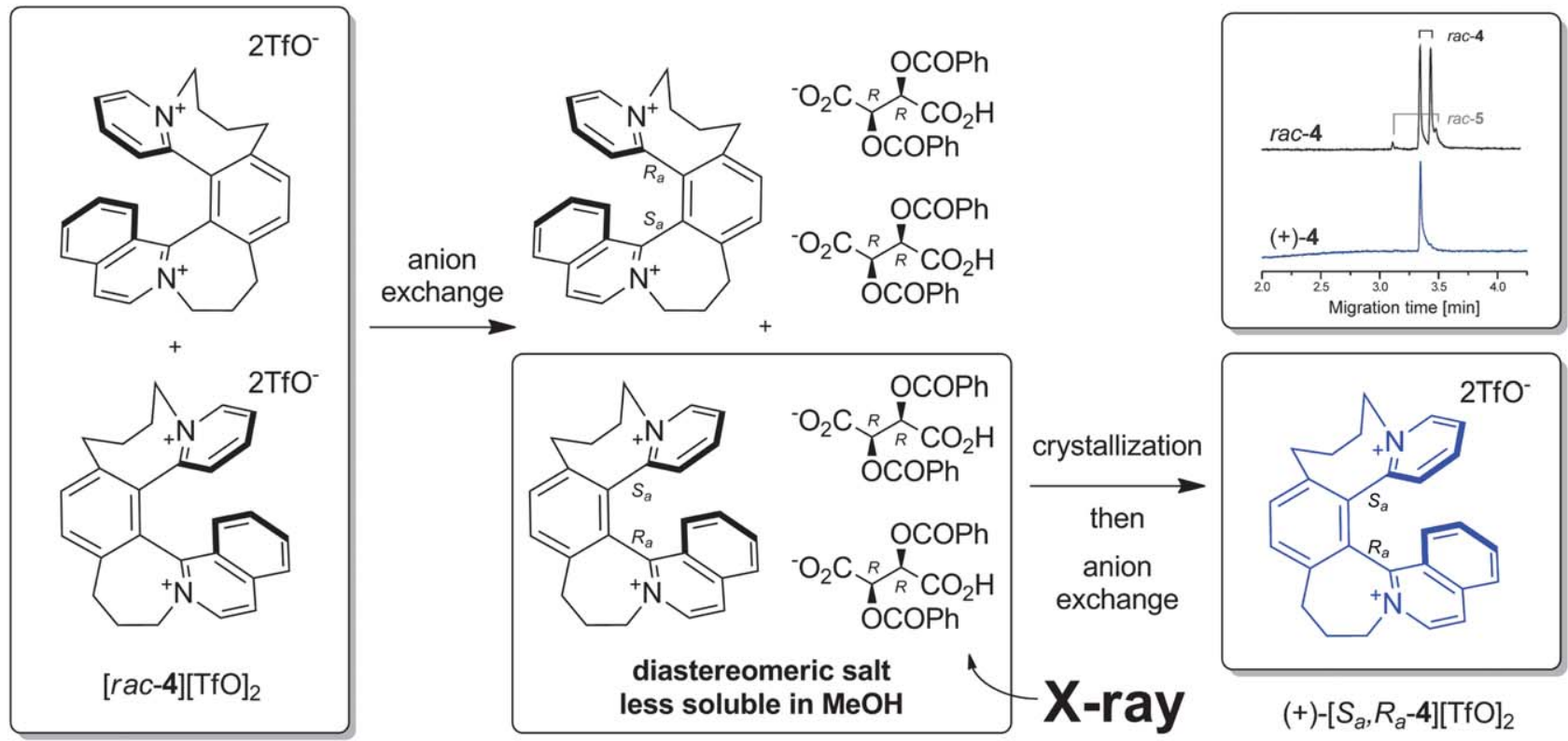

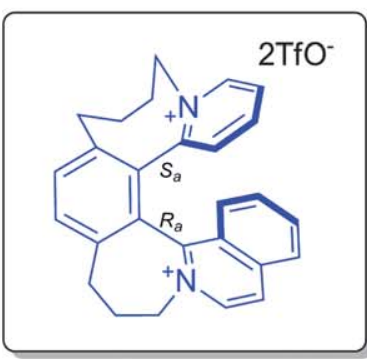

$(+)-\left[S_{a}, R_{a}-4\right][T f O]_{2}$

Scheme 7 Resolution procedure for $[\mathrm{rac}-4]\left[\mathrm{TfO}_{2}\right.$ and the corresponding CE traces showing two peaks for [ $\left.\mathrm{rac}-4\right]$ ditriflate and a single peak for the isolated (+)-[S $\left.S_{a}, R_{a}-4\right]$ ditriflate after resolution. See ESI for further details. $\dagger$

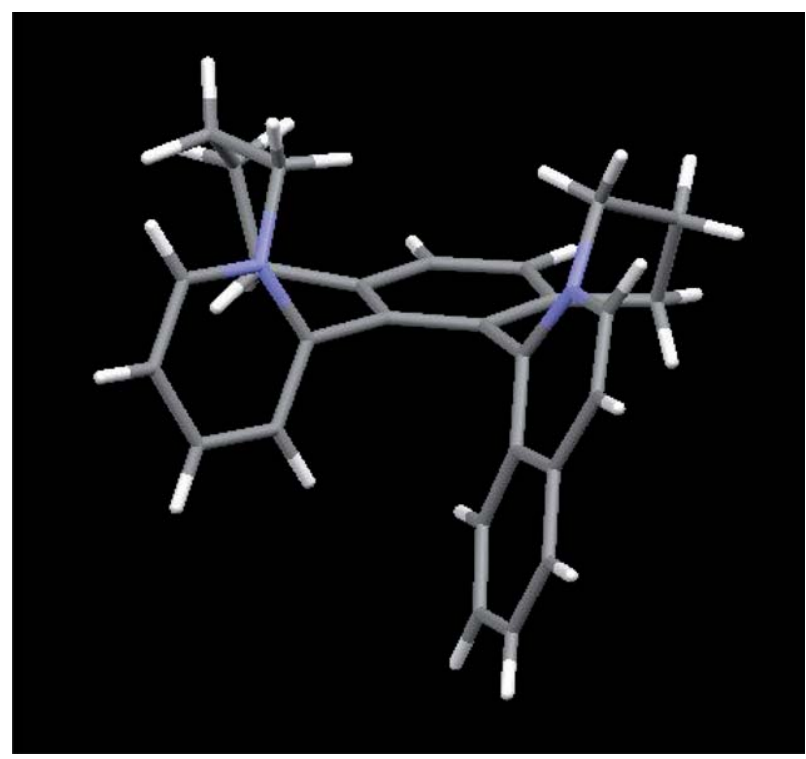

Fig. 1 X-Ray single crystal structure assigning absolute configuration of the dicationic framework of $(+)-\left[S_{a}, R_{a}-4\right][(R, R) \text {-dibenzoyltartrate }]_{2} .(R$, $R$ )-Dibenzoyltartrate anions and crystal water molecules are omitted for clarity. ${ }^{23}$

By heating this enantiopure sample of saddlequat (+)- $\left[S_{a}, R_{a^{-}}\right.$ 4] ditriflate at $100{ }^{\circ} \mathrm{C}$ in DMSO- $d_{6}$, we were able to confirm our hypothesis that the saddle-shaped species can indeed be transformed into enantiopure helquat [5] with no loss of chirality (Scheme 8). The experimental proof for this phenomenon was made possible by a powerful $\mathrm{CE}$ method using sulfated $\gamma$-cyclodextrin as a chiral selector. ${ }^{26,27}$ This provided us with an ideal experimental tool for monitoring the enantiocomposition of both [4] and [5] during the stereocontrolled transformation [4] $\rightarrow$ [5]. CE electropherograms show a single peak corresponding to the starting (+)- $\left[S_{a}, R_{a}-4\right]$ ditriflate giving rise to a single peak corresponding to $(-)-[5]$, providing definitive evidence for the complete stereocontrol governing this process (Scheme 8). The course of this stereocontrolled transformation $(+)-\left[S_{a}, R_{a}-4\right][\mathrm{TfO}]_{2} \rightarrow(-)-[5][\mathrm{TfO}]_{2}$ was also followed by ECD spectroscopy. During the transformation, the characteristic peaks of (+)-[S $\left.S_{a}, R_{a}-4\right]$ ditriflate gradually give way to peaks of (-)-[5] ditriflate positioned at longer wavelengths (Scheme 9).

To confirm that the saddlequat (+)- $\left[S_{a}, R_{a}-\mathbf{4}\right][\mathrm{TfO}]_{2}$ was transformed as predicted by calculation we sought the absolute configuration of the helquat (-)-[5][TfO $]_{2}$ formed during the process. Calculation predicted that in following the energetically more favorable pathway a, saddlequat $(+)-\left[S_{a}, R_{a}-4\right]$ would give rise to helquat [5] of $P$ helicity (Scheme 6). Single-crystal X-ray diffraction analyses confirmed that this was indeed the case (Fig. 2). ${ }^{23}$

To evaluate the racemization barrier of helquat [5] it was essential to have a non-racemic sample of the compound. In our hands, stereocontrolled transformation of enantiopure $(+)-\left[S_{a}, R_{a}-4\right]$ proved to be the only feasible method to access enantiopure samples of helquat [5] as independent attempts at resolution of racemic [5] via diastereomeric salts failed.

With a route to enantiopure helix 5 established, a solution of $(-)-[P-5]\left[\mathrm{TfO}_{2}\right.$ in DMSO was heated at $180{ }^{\circ} \mathrm{C}$. CE enantiocomposition analysis of samples taken over the course of heating determined the activation free energy value to be $\Delta G^{\neq}=153.3 \mathrm{~kJ}$ $\mathrm{mol}^{-1}$ and the racemization half-life $\left(T_{1 / 2}\right)$ to be $4.8 \mathrm{~h}$ at $180{ }^{\circ} \mathrm{C}$. This experimentally determined racemization barrier fits well with that predicted by DFT-D calculations, $\Delta G^{\neq}$of $157.7 \mathrm{~kJ}$ $\mathrm{mol}^{-1}$ (Scheme 10).

The consistent agreement between the experimental data and DFT-D calculations forms a body of evidence that can be best summarized in the dynamic visual form of the movie we present in the electronic table-of-contents. 


\section{Exclusive stereocontrol}

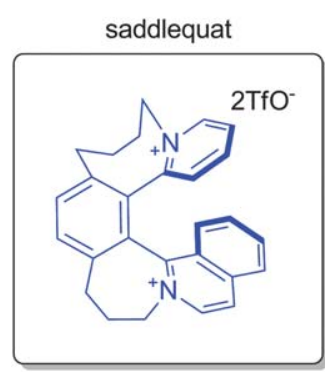

$(+)-\left[S_{a}, R_{a}-4\right][T f O]_{2}$

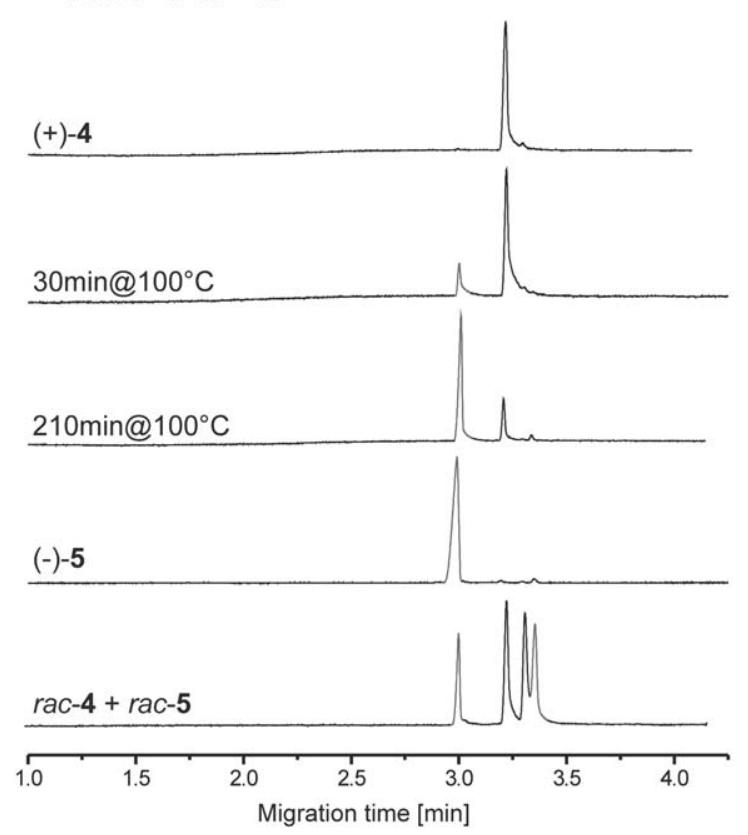

Scheme 8 Chiral CE monitoring confirms complete stereocontrol in the transformation of saddlequat (+)- $\left[S_{a}, R_{a}-\mathbf{4}\right][\mathrm{TfO}]_{2}$ to helquat (-)-[5] $[\mathrm{TfO}]_{2}$ at $100{ }^{\circ} \mathrm{C}$, as evidenced by the exclusive production of a single enantiomer of [5]. Bottom CE trace: reference mixture of [ $\mathrm{rac}-4]$ and $[\mathrm{rac}$ 5]. See ESI for details. $\dagger$

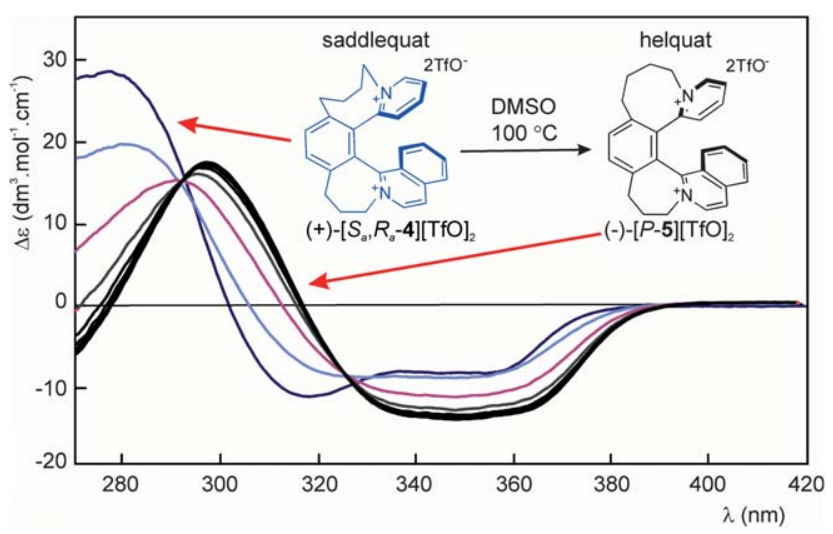

Scheme 9 ECD spectra recorded in the course of the stereocontrolled transformation (+)- $\left[S_{a}, R_{a}-4\right][\mathrm{TfO}]_{2} \rightarrow(-)-[5][\mathrm{TfO}]_{2}$ in DMSO at $100{ }^{\circ} \mathrm{C}$. See ESI for further details. $\dagger$

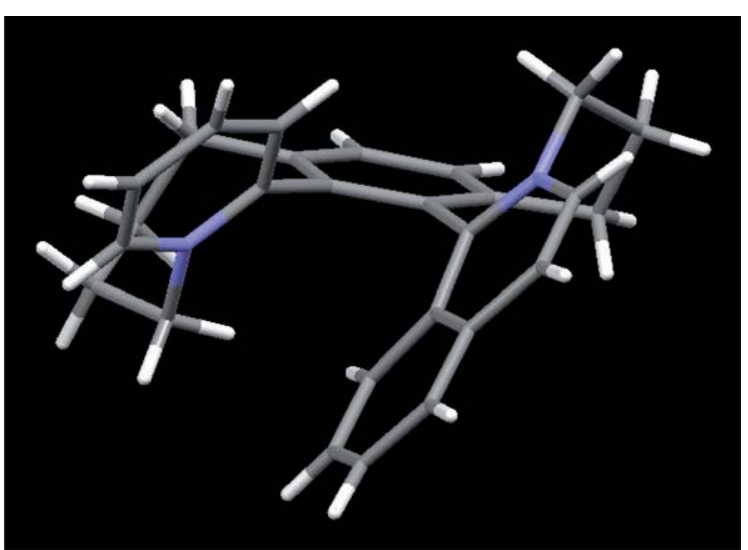

Fig. 2 X-Ray crystal structure assigning absolute configuration of helquat $(-)-[P-5][\mathrm{TfO}]_{2}$ as obtained by stereocontrolled transformation from saddlequat (+)-[S $\left.S_{a}, R_{a}-4\right][\mathrm{TfO}]_{2}$ at $100{ }^{\circ} \mathrm{C}$. X-Ray quality crystals were grown from the perchlorate salt of $[P-5]$. Perchlorate anions and crystal water molecules are omitted for clarity. ${ }^{23}$

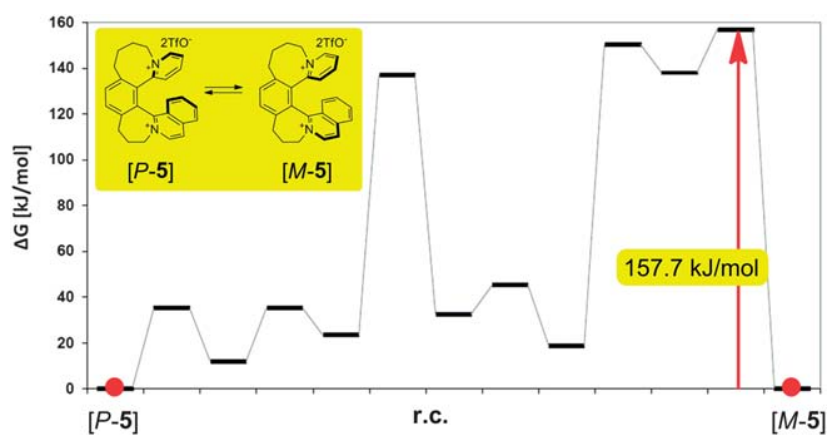

Scheme 10 Thermal racemization of helquat [5][TfO $]_{2}$ proceeds at 180 ${ }^{\circ} \mathrm{C}$ in DMSO with $T_{1 / 2}$ of $4.8 \mathrm{~h}$ (experimental $\Delta G^{\neq}=153.3 \mathrm{kJmol}^{-1}$, calculated $\Delta G^{\neq}=157.7 \mathrm{~kJ} \mathrm{~mol}^{-1}$ ). See ESI for details. $\dagger$

We note, that [6]helquat 5 represents an interesting example of a "rubber glove" molecule ${ }^{34,35}$ as its enantiomerization takes place exclusively by a chiral pathway via chiral [6]saddlequat 4 . As introduced by Mislow in the $1950 \mathrm{~s},{ }^{34}$ enantiomerization in "rubber glove" molecules can only proceed via chiral pathways as no achiral conformations can be attained for such structures. This molecular phenomenon is paralleled in the macroscopic world by turning a right-handed rubber glove inside-out leading to an object superimposable with a left handed-glove, never attaining an achiral (symmetric) conformation on its enantiomerization pathway.

\section{Conclusions}

In conclusion, we have presented a detailed experimental and theoretical investigation of a stereochemically rich $^{36}$ helicenetype racemization pathway featuring a saddle-shaped local energy minimum sufficiently stable to be isolated, characterized, and studied in detail. This saddle-shaped species arises from a kinetically controlled $\left[\mathrm{Rh}\left(\mathrm{PPh}_{3}\right)_{3} \mathrm{Cl}\right]$-catalyzed $[2+2+2]$ cycloisomerization of the triyne precursor ${ }^{37}$ Resolution of this chiral saddle species allows for production of enantiopure helix via a highly stereocontrolled chiral information transfer. ${ }^{38}$ 
Capillary electrophoresis with sulfated $\gamma$-cyclodextrin chiral selector is shown as an advantageous and direct method for analysis of enantiocomposition of both saddle- as well as helicalshaped charged species. Finally, this study describes [6]helquat 5 as an example of a "rubber glove" molecule and introduces [6]saddlequat 4 as an isolable chiral species lying on the entirely chiral enantiomerization pathway of [6]helquat 5.

\section{Acknowledgements}

Financial support from the Czech Science Foundation (203/09/ 1614, P207/10/2391, 203/08/1428, 203/09/P485) and IOCB (Z40550506) is gratefully acknowledged. IC thanks MSM0021620857 and PN thanks Specific University Research (MSMT No. 21/2011) for support. We are grateful to Dr L. Rulíšek, Mr M. Ončák, and Dr P. Slavíček for their valuable help in calculations.

\section{Notes and references}

1 For selected reviews on helicenes and heterohelicenes, see: (a) A. Rajca and M. Miyasaka, in Functional Organic Materials, ed. T. J. J. Müller and U. H. F. Bunz, Wiley-VCH, Weinheim, 2007, pp. 543-577; (b) A. Urbano, Angew. Chem., Int. Ed., 2003, 42, 3986; (c) H. Hopf, Classics in Hydrocarbon Chemistry: Syntheses, Concepts, Perspectives, Wiley-VCH, Weinheim, 2000, pp. 323-330; (d) T. J. Katz, Angew. Chem., Int. Ed., 2000, 39, 1921; (e) C. Schmuck, Angew. Chem., Int. Ed., 2003, 42, 2448; (f) S. K. Collins and M. P. Vachon, Org. Biomol. Chem., 2006, 4, 2518; (g) A. Rajca, S. Rajca, M. Pink and M. Miyasaka, Synlett, 2007, 1799; (h) I. Starý and I. G. Stará, in Strained Hydrocarbons, ed. H. Dodziuk, Wiley-VCH, Weinheim, 2009, pp. 166-204; (i) for discussion on early helicenes, see: C. A. Johnson II and M. M. Haley, in CarbonRich Compounds: From Molecules to Materials, ed. M. M. Haley and R. R. Tykwinski, Wiley-VCH, Weinheim, Germany, 2006, pp. $1-25$.

2 For early work, see: (a) M. S. Newman, W. B. Lutz and D. Lednicer, J. Am. Chem. Soc., 1955, 77, 3420; (b) M. S. Newman and D. Lednicer, J. Am. Chem. Soc., 1956, 78, 4765; (c) M. FlammangBarbieux, J. Nasielski and R. H. Martin, Tetrahedron Lett., 1967, 8, 743; (d) H. Wynberg and M. B. Groen, J. Am. Chem. Soc., 1968, 90, 5339; and reviews: (e) R. H. Martin, Angew. Chem., Int. Ed. Engl., 1974, 13, 649; (f) W. H. Laarhoven and W. J. C. Prinsen, Top. Curr. Chem., 1984, 125, 63; (g) H. Wynberg, Acc. Chem. Res., 1971, 4, 65; (h) K. P. Meurer and E. Vögtle, Top. Curr. Chem., 1985, 127, 1; (i) F. Vögtle, Fascinating Molecules in Organic Chemistry, Wiley, New York, 1992, p. 156; (j) G. Oremek, U. Seiffert and A. Janecka, Chem.-Ztg., 1987, 111, 69; (k) H. Osuga and H. Suzuki, J. Synth. Org. Chem. Jpn., 1994, 52, 1020.

3 For aza- and azoniahelicenes, see: (a) J. Guin, C. Besnard, P. Pattison and J. Lacour, Chem. Sci., 2011, 2, 425; (b) C. Herse, D. Bas, F. C. Krebs, T. Bürgi, J. Weber, T. Wesolowski, B. W. Laursen and J. Lacour, Angew. Chem., Int. Ed., 2003, 42, 3162; (c) B. Laleu, P. Mobian, C. Herse, B. W. Laursen, G. Hopfgartner, G. Bernardinelli and J. Lacour, Angew. Chem., Int. Ed., 2005, 44, 1879; (d) M. Ostermeier, C. Limberg, B. Ziemer and V. Karunakaran, Angew. Chem., Int. Ed., 2007, 46, 5329; (e) S. Arai, T. Yafune, M. Ohkubo and M. Hida, Tetrahedron Lett., 1989, 30, 7217; for reviews, see: (f) K. Sato, S. Arai, in Cyclophane Chemistry for the 21st Century, ed. H. Takemura, Research Signpost, Trivandrum, 2002, pp. 186-197; (g) F. Dumitrascu, D. G. Dumitrescu and I. Aron, Arkivoc, 2010, (i), 1.

4 For recent reports, see: D. Conreaux, N. Mehanna, C. Herse and J. Lacour, J. Org. Chem., 2011, 76, 2716; J. D. Chen, H. Y. Lu and C. F. Chen, Chem.-Eur. J., 2010, 16, 11843; L. Norel, M. Rudolph, N. Vanthuyne, J. A. G. Williams, C. Lescop, C. Roussel, J. Autschbach, J. Crassous and R. Réau, Angew. Chem., Int. Ed., 2010, 49, 99; S. Graule, M. Rudolph, W. Shen, J. A. G. Williams, C. Lescop, J. Autschbach, J. Crassous and R. Réau, Chem.-Eur. J., 2010, 16, 5976; Z. Wang, J. Shi, J. Wang, C. Li, X. Tian, Y. Cheng and H. Wang, Org. Lett., 2010, 12, 456; O. Songis, J. Míšek, M. B. Schmidt, A. Kollárovič, I. G. Stará, D. Šaman, I. Císařová and I. Starý, J. Org. Chem., 2010, 75, 6889; J. Štorch, J. Čermák, J. Karban, I. Císařová and J. Sýkora, J. Org. Chem., 2010, 75, 3137; I. Alkorta, F. Blanco, J. Elguero and D. Schröder, Tetrahedron: Asymmetry, 2010, 21, 962; Latorre, A. Urbano and M. C. Carreño, Chem. Commun., 2009, 6652; M. Miyasaka, M. Pink, S. Rajca and A. Rajca, Angew. Chem., Int. Ed., 2009, 48, 5954; C. L. Li, J. W. Shi, L. Xu, Y. G. Wang, Y. X. Chen and H. Wang, J. Org. Chem., 2009, 74, 408; J. Storch, J. Sýkora, J. Čermák, J. Karban, I. Císařová and A. Růžička, J. Org. Chem., 2009, 74, 3090; M. S. M. Pearson and D. R. Carbery, J. Org. Chem., 2009, 74, 5320; J. Cote and C. K. Collins, Synthesis, 2009, 1499; S. Graule, M. Rudolph, N. Vanthuyne, J. Autschbach, C. Roussel, J. Crassous and R. Réau, J. Am. Chem. Soc., 2009, 131, 3183; S. Goretta, C. Tasciotti, S. Mathieu, M. Smet, W. Maes, Y. M. Chabre, W. Dehaen, R. Giasson, J. M. Raimundo, C. R. Henry, C. Barth and M. Gingras, Org. Lett., 2009, 11, 3846; G. Pieters, A. Gaucher, D. Prim and J. Marrot, Chem. Commun., 2009, 4827; C. Kim, T. J. Marks, A. Facchetti, M. Schiavo, A. Bossi, S. Maiorana, E. Licandro, F. Todescato, S. Toffanin, M. Muccini, C. Graiff and A. Tiripicchio, Org. Electron., 2009, 10, 1511; F. Aloui, R. El Abed, A. Marinetti and B. Ben Hassine, C. R. Chim., 2009, 12, 284; F. Aloui and B. Ben Hassine, Tetrahedron Lett., 2009, 50, 4321; A. Grandbois and S. K. Collins, Chem.-Eur. J., 2008, 14, 9323; J. Ichikawa, M. Yokota, T. Kudo and S. Umezaki, Angew. Chem., Int. Ed., 2008, 47, 4870; H. Sugiura, R. Amemiya and M. Yamaguchi, Chem.-Asian J., 2008, 3, 244; M. Shimizu, I. Nagao, Y. Tomioka and T. Hiyama, Angew. Chem., Int. Ed., 2008, 47, 8096; G. Lamanna, C. Faggi, F. Gasparrini, A. Ciogli, C. Villani., P. J. Stephens, F. J. Devlin and S. Menichetti, Chem.-Eur. J., 2008, 14, 5747; L. Rulíšek, O. Exner, L. Cwiklik, P. Jungwirth, I. Starý, L. Pospíśil and Z. Havlas, J. Phys. Chem. C, 2007, 111, 14948; X. Xue and L. T. Scott, Org. Lett., 2007, 9, 3937.

5 T. Kaseyama, S. Furumi, X. Zhang, K. Tanaka and M. Takeuchi, Angew. Chem., Int. Ed., 2011, 50, 3684; P. Rahe, M. Nimmrich, A. Greuling, J. Schütte, I. G. Stará, J. Rybáček, G. Huerta-Angeles, I. Starý, M. Rohlfing and A. Kühnle, J. Phys. Chem. C, 2010, 114, 1547; M. A. Shcherbina, X. B. Zeng, T. Tadjiev, G. Ungar, S. H. Eichhorn, K. E. S. Phillips and T. J. Katz, Angew. Chem., Int. Ed., 2009, 48, 7837; R. Fasel, M. Parschau and K.-H. Ernst, Nature, 2006, 439, 449.

6 For molecular recognition with helicenoids, see: M. T. Reetz and S. Sostmann, Tetrahedron, 2001, 57, 2515; K. Yamamoto, T. Ikeda, T. Kitsuki, Y. Okamoto, H. Chikamatsu and M. Nakazaki, J. Chem. Soc., Perkin Trans. 1, 1990, 271; D. J. Weix, S. D. Dreher and T. J. Katz, J. Am. Chem. Soc., 2000, 122, 10027; E. Murguly, R. McDonald and N. R. Branda, Org. Lett., 2000, 2, 3169; L. Owens, C. Thilgen, F. Diederich and C. B. Knobler, Helv. Chim. Acta, 1993, 76, 2757.

7 (a) J. Chen, B. Captain and N. Takenaka, Org. Lett., 2011, 13, 1654; (b) M. R. Crittall, H. S. Rzepa and D. R. Carbery, Org. Lett., 2011, 13, 1250; (c) M. Śámal, J. Míšek, I. G. Stará and I. Starý, Collect. Czech. Chem. Commun., 2009, 74, 1151; (d) N. Takenaka, J. Chen, B. Captain, R. S. Sarangthem and A. Chandrakumar, J. Am. Chem. Soc., 2010, 132, 4536; (e) N. Takenaka, R. S. Sarangthem and B. Captain, Angew. Chem., Int. Ed., 2008, 47, 9708; (f) J. S. Chen and N. Takenaka, Chem.-Eur. J., 2009, 15, 7268; (g) M. T. Reetz, E. W. Beuttenmüller and R. Goddard, Tetrahedron Lett., 1997, 38, 3211; (h) A. Terfort, H. Görls and H. Brunner, Synthesis, 1997, 79; (i) M. T. Reetz and S. Sostmann, J. Organomet. Chem., 2000, 603, 105; (j) A. Aloui, R. El Abed, A. Marinetti and B. Ben Hassine, Tetrahedron Lett., 2007, 48, 2017; (k) I. Sato, R. Yamashima, K. Kadowaki, J. Yamamoto, T. Shibata and K. Soai, Angew. Chem., Int. Ed., 2001, 40, 1096; (l) H. Okubo, M. Yamaguchi and C. Kabuto, J. Org. Chem., 1998, 63, 9500; (m) S. D. Dreher, T. J. Katz, K.-C. Lam and A. L. Rheingold, J. Org. Chem., 2000, $\mathbf{6 5}, 815$.

8 T. Verbiest, S. Van Elshocht, M. Kauranen, L. Hellemans, J. Snauwaert, C. Nuckolls, T. J. Katz and A. Persoons, Science, 1998, 282, 913; C. Nuckolls, T. J. Katz, G. Katz, P. J. Collings and L. Castellanos, J. Am. Chem. Soc., 1999, 121, 79; C. Nuckolls, T. J. Katz and L. Castellanos, J. Am. Chem. Soc., 1996, 118, 3767; T. J. Wigglesworth, D. Sud, T. B. Norsten, V. S. Lekhi and N. R. Branda, J. Am. Chem. Soc., 2005, 127, 7272; E. Botek, 
B. Champagne, M. Turki and J.-M. André, J. Chem. Phys., 2004, 120, 2042; C. Nuckolls, T. J. Katz, T. Verbiest, S. Van Elshocht, H.-G. Kuball, S. Kiesewalter, A. J. Lovinger and A. Persoons, $J$. Am. Chem. Soc., 1998, 120, 8656.

9 S. Ehala, J. Míšek, I. G. Stará, I. Starý and V. Kašička, J. Sep. Sci., 2686, 2008, 31; J. Míšek, M. Tichý, I. G. Stará, I. Starý, J. Roithová and D. Schröder, Croat. Chem. Acta, 2009, 82, 79.

10 K. Shinohara, Y. Sannohe, S. Kaieda, K. Tanaka, H. Osuga, H. Tahara, Y. Xu, T. Kawase, T. Bando and H. Sugiyama, J. Am. Chem. Soc., 2010, 132, 3778.

11 S. Basili, G. Basso, A. Faccio, A. Granzhan, H. Ihmels, S. Moro and G. Viola, ChemMedChem, 2008, 3, 1671.

12 Y. Xu, Y. X. Zhang, H. Sugiyama, T. Umano, H. Osuga and K. Tanaka, J. Am. Chem. Soc., 2004, 126, 6566; S. Honzawa, H. Okubo, S. Anzai, M. Yamaguchi, K. Tsumoto and I. Kumagai, Bioorg. Med. Chem., 2002, 10, 3213.

13 A. Granzhan, H. Ihmels and K. Jäger, Chem. Commun., 2009, 1249.

14 For an excellent overview, see: C. Wolf, Dynamic Stereochemistry of Chiral Compounds, RSC Publishing, Cambridge, UK, 2008, pp. 5354; for early studies: K. Yamada, H. Nakagawa and H. Kawazura, Bull. Chem. Soc. Jpn., 1986, 59, 2429; R. H. Martin and M. J. Marchant, Tetrahedron, 1974, 30, 347; R. H. Martin and M. J. Marchant, Tetrahedron Lett., 1972, 13, 3707; C. Goedicke and H. Stegemeyer, Tetrahedron Lett., 1970, 11, 937; H. Wynberg and M. B. Groen, J. Chem. Soc. D, 1969, 964; D. M. Hall, J. Chem. Soc., 1956, 3674; A. Mannschreck, E. Gmahl, T. Burgemeister, F. Kastner and V. Sinnwell, Angew. Chem., Int. Ed. Engl., 1988, 27, 270; R. H. Martin and V. Libert, J. Chem. Res. (S), 1980, 30, 130; ref. $2 a, 2 b, 2 e, 2 f$.

15 For recent studies: ref. $3 b$, J. Guin, C. Besnard and J. Lacour, Org. Lett., 2010, 12, 1748; G. Pieters, A. Gaucher, S. Marque, F. Maurel, P. Lesot and D. Prim, J. Org. Chem., 2010, 75, 2096; M. Llunell, P. Alemany and J. M. Bofill, ChemPhysChem, 2008, 9, 1117; M. C. Carreño, A. Enríquez, S. García-Cerrada, M. J. SanzCuesta, A. Urbano, F. Maseras and A. Nonell-Canals, Chem.-Eur. $J ., 2008,14,603$; K. Shiraishi, A. Rajca, M. Pink and S. Rajca, $J$. Am. Chem. Soc., 2005, 127, 9312; Z. Y. Wang, E. K. Todd, X. S. Meng and J. P. Gao, J. Am. Chem. Soc., 2005, 127, 11552; A. Rajca, M. Miyasaka, M. Pink, H. Wang and S. Rajca, J. Am. Chem. Soc., 2004, 126, 15211; F. Lebon, G. Longhi, F. Gangemi, S. Abbate, J. Priess, M. Juza., C. Bazzini, T. Caronna and A. Mele, J. Phys. Chem. A, 2004, 108, 11752.

16 For theoretical studies, see: (a) S. Grimme and S. D. Peyerimhoff, Chem. Phys., 1996, 204, 411; (b) R. H. Janke, G. Haufe, E. U. Würthwein and J. H. Borkent, J. Am. Chem. Soc., 1996, 118, 6031; (c) H. J. Lindner, Tetrahedron, 1975, 31, 281; (d) J. H. Borkent and W. H. Laarhoven, Tetrahedron, 1978, 34, 2565.

17 For a predicted [11]anthrahelicene saddle-shaped intermediate, see: P. Sehnal, I. G. Stará, D. Šaman, M. Tichý, J. Míšek, J. Cvačka, L. Rulíšek, J. Chocholoušová, J. Vacek, G. Goryl, M. Szymonski, I. Císařová and I. Starý, Proc. Natl. Acad. Sci. U. S. A., 2009, 106, 13169.

18 An interesting strategy to fix the saddle-shaped helicene species has been recently proposed in a theoretical paper by Patzschke and Johansson: M. P. Johansson and M. Patzschke, Chem.-Eur. J., 2009, 15, 13210.

19 L. Adriaenssens, L. Severa, T. Šálová, I. Císařová, R. Pohl, D. Šaman, S. V. Rocha, N. S. Finney, L. Pospíśil, P. Slavíček and F. Teplý, Chem.-Eur. J., 2009, 15, 1072.

20 L. Severa, D. Koval, P. Novotná, M. Ončák, P. Sázelová, D. Šaman, P. Slavíček, M. Urbanová, V. Kašička and F. Teplý, New J. Chem., 2010, 34, 1063.

21 L. Severa, L. Adriaenssens, J. Vávra, D. Šaman, I. Císařová, P. Fiedler and F. Teplý, Tetrahedron, 2010, 66, 3537.

22 L. Pospíšil, F. Teplý, M. Gál, L. Adriaenssens, M. Horáček and L. Severa, Phys. Chem. Chem. Phys., 2010, 12, 1550.

$23[\mathrm{rac}-2]\left[\mathrm{PF}_{6}\right]_{2}\left(\mathrm{CCDC}\right.$ 829266), $[\mathrm{rac}-5][\mathrm{TfO}]_{2}$ (CCDC 829267), $\left[S_{a}, R_{a^{-}}\right.$ $4][(R, R) \text {-dibenzoyl tartrate }]_{2}(\mathrm{CCDC} 828959)$, and $[P-5]\left[\mathrm{ClO}_{4}\right]_{2}$ (CCDC 829265) $\dagger$.

24 Intramolecular $[2+2+2]$ cycloaddition as an entry to non-ionic helical scaffolds was pioneered in the group of Stará and Starý, for initial reports, see: (a) I. G. Stará, I. Starý, A. Kollárovič, F. Teplý, D. Šaman and M. Tichý, J. Org. Chem., 1998, 63, 4046; (b) I. G. Stará, I. Starý, A. Kollárovič, F. Teplý, Ş. Vyskočil and D. Śaman, Tetrahedron Lett., 1999, 40, 1993; (c) F. Teplý,
I. G. Stará, I. Starý, A. Kollárovič, D. Šaman, L. Rulíšek and P. Fiedler, J. Am. Chem. Soc., 2002, 124, 9175; for further reports see also: (d) K. Tanaka, N. Fukawa, T. Suda and K. Noguchi, Angew. Chem., Int. Ed., 2009, 48, 5470; (e) K. Tanaka, A. Kamisawa, T. Suda, K. Noguchi and M. Hirano, J. Am. Chem. Soc., 2007, 129, 12078; $(f)$ S. Han, A. D. Bond, R. L. Disch, D. Holmes, J. M. Schulman, S. J. Teat, K. P. C. Vollhardt and G. D. Whitener, Angew. Chem., Int. Ed., 2002, 41, 3223; see also overview in: (g) A. Rajca and S. Rajca, Angew. Chem., Int. Ed., 2010, 49, 672, and ref. $7 b, 17$.

25 Ratio of [4]: [5] $(4: 1)$ determined by integration of peaks in NMR spectra after the cyclization experiment conducted at $105{ }^{\circ} \mathrm{C} / 30$ $\min$. See ESI $\dagger$.

26 For enantiocomposition analysis of helquats by CE, see ref. 20 and: D. Koval, L. Severa, L. Adriaenssens, J. Vávra, F. Teplý and V. Kašička, Electrophoresis, 2011, DOI: 10.1002/elps.201100173.

27 Sulfated $\gamma$-cyclodextrin sodium salt was obtained from BeckmanCoulter as $20 \mathrm{wt} \%$ solution in water (cat. no. A50924).

28 P. Sehnal, Z. Krausová, F. Teplý, I. G. Stará, I. Starý, L. Rulíšek, D. Šaman and I. Císařová, J. Org. Chem., 2008, 73, 2074; A. Andronová, F. Szydlo, F. Teplý, M. Tobrmanová, A. Volot, I. G. Stará, I. Starý, L. Rulísek, D. Šaman, J. Cvačka, P. Fiedler and P. Vojtíšek, Collect. Czech. Chem. Commun., 2009, 74, 189.

29 TURBOMOLE V6.1 2009, University of Karlsruhe and Forschungszentrum Karlsruhe GmbH, 1989-2007, TURBOMOLE $\mathrm{GmbH}$, since 2007, available from http://www.turbomole.com.

30 (a) S. Grimme, J. Comput. Chem., 2004, 25, 1463; (b) S. Grimme, J. Comput. Chem., 2006, 27, 1787.

31 COSMO model: (a) A. Klamt and G. Schuurmann, J. Chem. Soc., Perkin Trans. 2, 1993, 799; (b) A. Schäfer, A. Klamt, D. Sattel, J. C. W. Lohrenz and F. Eckert, Phys. Chem. Chem. Phys., 2000, 2, 2187.

32 The energy difference between species $\mathbf{4}$ and $\mathbf{5}$ is similar for the calculations performed with ditriflates in the gas phase.

33 For a recent successful resolution of non-ionic 1-aza[6]helicene via its dibenzoyltartrate diastereoisomeric salts, see: J. Míšek, F. Teplý, I. G. Stará, M. Tichý, D. Šaman, I. Císařová, P. Vojtíšek and I. Starý, Angew. Chem., Int. Ed., 2008, 47, 3188.

34 (a) K. Mislow, Science, 1954, 120, 232; (b) K. Mislow and R. Bolstad, J. Am. Chem. Soc., 1955, 77, 6712.

35 Specifically [6]helquat 5 is an example of a "Euclidean rubber glove" molecule, see: J. C. Chambron, J. P. Sauvage, K. Mislow, A. De Cian and J. Fischer, Chem.-Eur. J., 2001, 7, 4085.

36 For further examples of aromatics with interesting conformation behaviour and shape, see: G. S. Kottas, L. I. Clarke, D. Horinek and J. Michl, Chem. Rev., 2005, 105, 1281; A. R. Karim, A. Linden, K. K. Baldridge and J. S. Siegel, Chem. Sci., 2010, 1, 102; T. A. V. Khuong, J. E. Nuñez, C. E. Godinez and M. A. GarciaGaribay, Acc. Chem. Res., 2006, 39, 413; R. Eelkema, M. M. Pollard, J. Vicario, N. Katsonis, B. Serrano Ramon, C. W. M. Bastiaansen, D. J. Broer and B. L. Feringa, Nature, 2006, 440, 163; T. R. Kelly, H. De Silva and R. A. Silva, Nature, 1999, 401, 150; R. S. Walters, C. M. Kraml, N. Byrne, D. M. Ho, Q. Qin, F. J. Coughlin, S. Bernhard and R. A. Pascal Jr, J. Am. Chem. Soc., 2008, 130, 16435; R. A. Pascal Jr, Chem. Rev., 2006, 106, 4809; C. L. Hilton, J. M. Crowfoot, P. Rempala and B. T. King, J. Am. Chem. Soc., 2008, 130, 13392; Y. Wang, A. D. Stretton, M. C. McConnell, P. A. Wood, S. Parsons, J. B. Henry, A. R. Mount and T. H. Galow, J. Am. Chem. Soc., 2007, 129, 13193; M. S. Betson, J. Clayden, C. P. Worrall and S. Peace, Angew. Chem., Int. Ed., 2006, 45, 5803; D. Zehm, W. Fudickar and T. Linker, Angew. Chem., Int. Ed., 2007, 46, 7689; D. Ajami, O. Oeckler, A. Simon and R. Herges, Nature, 2003, 426, 819.

37 During preparation of this manuscript an interesting saddle-shaped system was isolated and introduced by Bertozzi et al. However, it has not been studied in the context of its transformation to the corresponding helix. Interestingly, synthesis of this saddle-shaped system relies on non-catalyzed intermolecular $[2+2+2]$ cycloaddition, see: E. M. Sletten, H. Nakamura, J. C. Jewett and C. R. Bertozzi, J. Am. Chem. Soc., 2010, 132, 11799.

38 For a recent report on isomerization of bis(metallahelicene), see: E. Anger, M. Rudolph, C. Shen, N. Vanthuyne, L. Toupet, C. Roussel, J. Autschbach, J. Crassous and R. Réau, J. Am. Chem. Soc., 2011, 133, 3800 . 